\title{
Synthesis, photophysical property study of novel fluorescent 4-(1,3-benzoxazol-2-yl)-2-phenylnaphtho[1,2-d][1,3] oxazole derivatives and their antimicrobial activity
}

\author{
KIRAN R PHATANGARE, BHUSHAN N BORSE, VIKAS S PADALKAR, VIKAS S PATIL, \\ VINOD D GUPTA, PRASHANT G UMAPE and N SEKAR* \\ Department of Intermediate and Dyestuff Technology, Institute of Chemical Technology (Formerly UDCT), \\ NP Marg, Matunga, Mumbai 400 019, India \\ e-mail: n.sekar@ictmumbai.edu.in,nethi.sekar@gmail.com
}

MS received 23 December 2011; revised 28 July 2012; accepted 10 August 2012

\begin{abstract}
A series of 4-(1,3-benzoxazol-2-yl)-2-phenylnaphtho[1,2-d][1,3]oxazole derivatives have been synthesized from intermediate 1-amino-3-(1,3-benzoxazol-2-yl)naphthalen-2-ol. This intermediate was obtained by coupling 3-(1,3-benzoxazol-2-yl)naphthalen-2-ol with 4-sulphobenzenediazonium chloride followed by reduction with sodium dithionate in water at $\mathrm{pH}$ 8-9. 3-(1,3-benzoxazol-2-yl)naphthalen-2-ol was synthesized from 3-hydroxynaphthalene-2-carboxylic acid and 2-amino phenol in the presence of $\mathrm{PCl}_{3}$ in chlorobenzene at $130-135^{\circ} \mathrm{C}$. All these compounds were characterized by FT-IR, ${ }^{1} \mathrm{H}$ NMR, mass spectral and elemental analysis. The synthesized compounds are fluorescent which absorbs in the range of 296 to $332 \mathrm{~nm}$ while emits in the ranges of 368 to $404 \mathrm{~nm}$ with excellent quantum yield. All compounds were evaluated for in vitro antibacterial activities against Escherichia coli and Staphylococcus aureus strains and in vitro antifungal activity against Candida albicans and Aspergillus niger strains by using serial dilution method.
\end{abstract}

Keywords. Heterocyclic synthesis; benzoxazole; naphthoxazole; fluorescence; photophysical properties; antibacterial activity; antifungal activity.

\section{Introduction}

Benzoxazoles and naphthoxazoles are important class of heterocyclic compounds because of their wide spectrum of biological and photochromatic activities. 2Substituted naphthoxazole is a major subunit occurring in a number of biologically active compounds ${ }^{1}$ and natural products. ${ }^{2}$ They find extensive use as fluorescent probes ${ }^{3}$ and as intermediates for dyes. ${ }^{4}$ Orthosubstituted naphthoxazole derivatives show promising inhibitory activity for protein tyrosine phosphatase-1B (PTB-1B) and in vivo antidiabetic activity in SLM, STZ-S and db/db mice models. ${ }^{5-7}$

A number of benzoxazole and naphthoxazole derivatives possessing antifungal, ${ }^{8}$ antiinflammatory, ${ }^{9}$ antitumour ${ }^{10}$ and antiHIV ${ }^{11}$ activities have been reported. Some of the benzoxazole derivatives exhibit diverse chemotherapeutic activity including anticancer agent ${ }^{12}$ NSC-693638 and antibacterial agents; ${ }^{13}$ some examples are UK-1, MUK-1 and DMUK-1 (figure 1).
The excellent photophysical properties like broad spectral windows, high molar absorptivity values and reasonably good fluorescence quantum efficiency have made them to be of use as fluorescent probe and sensing materials. ${ }^{14}$ In material chemistry, benzoxazoles find applications as laser dyes and photochromatic agents. ${ }^{15}$ Some of the phenylaminonaphtho[1,2- $d$ ] oxazol-2-yltype compounds were reported as a sensor for water in organic solvents by photo-induced electron transfer (PET). ${ }^{16}$

There are reports available describing the synthesis and biological activity of naphtho[1,2- $d][1,3]$ oxazole $^{5}$ and benzoxazole ${ }^{17}$ separately. However, there are no reports available describing synthesis and biological activity of benzoxazole derivatives incorporated with naphthoxazole heterocycles in a single moiety. Therefore, as a part of ongoing research work on synthesis of biologically important fused heterocycles, ${ }^{18}$ we report here the synthesis of novel 4-(1,3-benzoxazol-2-yl)-2phenylnaphtho[1,2- $d][1,3]$ oxazole derivatives and their antimicrobial activity study.

The synthesized derivatives are the structural analogues of bis(benzoxazole) natural product UK-1 (scheme 1), a secondary metabolite with interesting biological activity. This UK-1 was also found to be

*For correspondence 


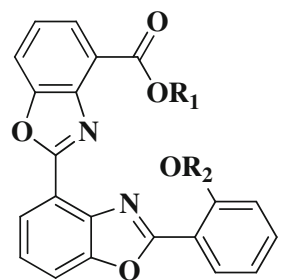

UK-1 $\left(\mathbf{R}_{1}=\mathrm{Me}, \mathbf{R}_{2}=\mathbf{H}\right)$

$\operatorname{MUK}-1\left(R_{1}=M e, R_{2}=M e\right)$

DMUK-1 $\left(\mathbf{R}_{1}=\mathbf{H}, \mathbf{R}_{\mathbf{2}}=\mathbf{H}\right)$

Figure 1. Various bioactive molecules containing benzoxazole.

fluorescent, on excitation at $335 \mathrm{~nm}$, it emits at $530 \mathrm{~nm}$. It binds to double strand DNA 10 times more tightly in the presence of $\mathrm{Mg}^{2+}$ than in its absence. The decrease in emission intensity is the detection tool for its binding with DNA strand. It is also used as inhibitor of human topoisomerase II. ${ }^{19}$ It shows wide spectrum of potential anticancer activity against leukemia, lymphoma, and certain solid tumour derived cell lines. ${ }^{20}$ The benzoxazole derivatives are used as fluorescent probes ${ }^{21,22}$ and sensors for the detection of different metal ions. ${ }^{23,24}$ In this study, one of the 1,3-benzoxazole ring of UK-1 is replaced by naphtho[1,2- $d][1,3]$ oxazole ring and studied for their biological activities.

\section{Experimental}

All commercial reagents were used as received without purification and all solvents were reagent grade. The reaction was monitored by TLC using $0.25 \mathrm{~mm}$ EMerck silica gel 60 F254 precoated plates, which were visualized with UV light. Melting points were measured on standard melting point apparatus from Sunder Industrial Product, Mumbai and were uncorrected. The FT-IR spectra were recorded on a Perkin Elmer 257 spectrometer using $\mathrm{KBr}$ discs. ${ }^{1} \mathrm{H}$ NMR spectra were recorded on a Varian Cary Eclipse Australia, MR$300 \mathrm{MHz}$, USA instrument using TMS as an internal standard. Mass spectra were recorded on Finnigan Mass spectrometer. The absorption spectra of the compounds were recorded on a Spectronic Genesys 2 UV-Visible spectrophotometer; UV-Visible emission spectra were recorded on JASCO - FP 1520. Simultaneous DSCTGA measurements were performed on simultaneous DSC-TGA Waters (India) Pvt. Ltd.

\subsection{Experimental procedure for the synthesis} of 3-(1,3-benzoxazol-2-yl)naphthalen-2-ol (3)

A mixture of 2-aminophenol $2(1.09 \mathrm{~g}, 0.01 \mathrm{~mol})$ and 3-hydroxynaphthalene-2-carboxylic acid $\mathbf{1}$ (1.88 g, $0.01 \mathrm{~mol})$ was refluxed $\left(133-135^{\circ} \mathrm{C}\right)$ in chlorobenzene<smiles>Nc1ccccc1O</smiles><smiles>Nc1ccc(S(=O)(=O)O)cc1</smiles><smiles>Nc1c(O)c(-c2nc3ccccc3o2)cc2ccccc12</smiles>

Scheme 1. Synthesis of 1-amino-3-(1,3 benzoxazol-2-yl)naphthalene-2ol (7). Reagents and conditions: (a) $\mathrm{PCl}_{3}$, Chlorobenzene, Reflux (133$135^{\circ} \mathrm{C}$ ), 4 h, 80\%; (b) $\mathrm{NaNO}_{2}, \mathrm{HCl}, 0-5^{\circ} \mathrm{C}, 45 \mathrm{~min}, 98 \%$; (c) Methanol: Water, pH 8-9, 0-5 $5^{\circ} \mathrm{C}$ (80: 20) $3 \mathrm{~h}, 90 \%$; (d) $\mathrm{Na}_{2} \mathrm{~S}_{2} \mathrm{O}_{4}, \mathrm{NaOH}, \mathrm{H}_{2} \mathrm{O}, 90^{\circ} \mathrm{C}$, $1.5 \mathrm{~h}, 66 \%$. 
$(10 \mathrm{~mL})$ in the presence of $\mathrm{PCl}_{3}(2 \mathrm{~g}, 1.3 \mathrm{~mL}, 0.01 \mathrm{~mol})$ for $4 \mathrm{~h}$. After completion of reaction, the solid product was precipitated out and was filtered to get crude product 3 (yield 80\%) which was further recrystalized form ethanol.

\subsection{Experimental procedure for the synthesis of 4-\{[3-(1,3-benzoxazol-2-yl)-2-hydroxynaphthalen- 1-yl]diazenyl benzenesulphonic acid (6)}

Sulphanilic acid 4 (2.07 g, $0.012 \mathrm{~mol})$ was dissolved in water $(10 \mathrm{~mL})$ containing sodium carbonate of $(0.62 \mathrm{~g})$ at $50-55^{\circ} \mathrm{C}$. A solution $\mathrm{NaNO}_{2}(0.84 \mathrm{~g}$, $0.012 \mathrm{~mol})$ in water $(10 \mathrm{~mL})$ was added to sulphanilic acid solution in water and then this mixture was added slowly to the conc. $\mathrm{HCl}(4 \mathrm{~mL})$ at $0-5^{\circ} \mathrm{C}$ for $30 \mathrm{~min}$ and further stirred at this temperature for $1.5 \mathrm{~h}$ to get 4-sulphobenzenediazonium chloride salt $\mathbf{5}$. This was further coupled with the 3-(1,3-benzoxazol-2yl)naphthalene-2-ol $3(2.61 \mathrm{~g}, 0.010 \mathrm{~mol})$ at $0-5^{\circ} \mathrm{C}$ at $\mathrm{pH} 8-9$ for $3 \mathrm{~h}$ and then at room temperature for $1 \mathrm{~h}$ in methanol:water mixture $(80: 20)$. Then reaction mixture was neutralized with acetic acid $(9-10 \mathrm{~mL})$ at $\mathrm{pH} 7$, methanol was removed under reduced pressure and then filtered out to afford 4-\{[3-(1,3-benzoxazol-2-yl)-2hydroxynaphthalen-1-yl]diazenyl $\}$ benzenesulphonic acid 6 (yield 90\%).

\subsection{Experimental procedure for the synthesis} of 1-amino-3-(1,3-benzoxazol-2-yl)naphthalen-2-ol (7)

The azo compound $6(4.45 \mathrm{~g}, 0.010 \mathrm{~mol})$ was heated in water containing $\mathrm{NaOH}(3.51 \mathrm{~g}, 0.088)$ at $50^{\circ} \mathrm{C}$ and sodium dithionate $(3.78 \mathrm{~g}, 0.025 \mathrm{~mol})$ was added at $90^{\circ} \mathrm{C}$ in portions over period of $1 \mathrm{~h}$. The mixture was heated at $90^{\circ} \mathrm{C}$ at $\mathrm{pH} 8-9$ until the colour of azo get disappeared $(1.5 \mathrm{~h})$. The progress of the reaction was monitored by TLC. After completion of reaction, the reaction mass was neutralized up to $\mathrm{pH} 7$, filtered and washed well with water $2-3$ times and dried well to afford crude 1-amino-3-(1,3-benzoxazol2 -yl)naphthalen-2-ol 7 in $66 \%$ yield. Crude product was recrystalized in ethyl alcohol.

2.4 General experimental procedure for the synthesis of 4-(1,3-benzoxazol-2-yl)-2-phenylnaphtho[1,2d] [1,3]oxazole derivatives from intermediate 7 and substituted aromatic acids (8-11)

1-Amino-3-(1,3-benzoxazol-2-yl) naphthalen-2-ol 7 $(0.010 \mathrm{~mol})$, corresponding substituted aromatic acid $(0.010 \mathrm{~mol})$ and $\mathrm{PCl}_{3}(0.015 \mathrm{~mol})$ were refluxed in chlo- robenzene $\left(130-133^{\circ} \mathrm{C}\right)(6 \mathrm{~mL})$ up to the completion of reaction (16-18 h) and was confirmed by TLC. After cooling the reaction mass, solid product was filtered out and recrystalized from chloroform to afford corresponding compounds 8-11 in 57-65\% yield.

2.5 General experimental procedure for the synthesis of 4-(1,3-benzoxazol-2-yl)-2-phenylnaphtho[1,2d] $[1,3]$ oxazole derivatives from intermediate 7 and substituted aromatic aldehydes (8-11)

1-Amino-3-(1,3-benzoxazol-2-yl) naphthalen-2-ol 7 $(0.010 \mathrm{~mol})$ and corresponding aromatic substituted aldehydes $(0.010 \mathrm{~mol})$ were heated in dimethylsulphoxide $(6 \mathrm{~mL})$ at $158-160^{\circ} \mathrm{C}$ up to the completion of reaction (10-12 h), confirmed by TLC. After cooling the reaction mass, solid product was filtered out and recrystalized form chloroform to afford corresponding compounds 8-11 in 62-72\% yield.

2.6 Experimental procedure for the synthesis of 4-(1,3-benzoxazol-2-yl)-2-methylnaphtho [1,2-d] [1,3] oxazole (12)

1-Amino-3-(1,3-benzoxazol-2-yl)naphthalen-2-ol (1.38 g, $0.005 \mathrm{~mol}) 7$ was refluxed in the presence of acetic anhydride $(5 \mathrm{~mL})$ up to completion of reaction $(30 \mathrm{~min})$ which was confirmed by TLC. Reaction mass was cooled and slowly poured on crushed ice with efficient stirring. Solid product was filtered out and recrystalized form ethyl alcohol to afford compound $\mathbf{1 2}$ in $\mathbf{7 3 \%}$ yields.

\subsection{Spectral data of compounds (7-12)}

2.7a 1-Amino-3-(1,3-benzoxazol-2-yl)naphthalen-2-ol (7): Mp: $206-208^{\circ} \mathrm{C}$. FT-IR (KBr): 3510, 3452, 3357 $\left(-\mathrm{NH}_{2},-\mathrm{OH}\right), 3028$ (Aromatic -CH Stretching), 1615, $1585,1477,(\mathrm{C}=\mathrm{C}, \mathrm{C}=\mathrm{N}$ ring stretching $), 1222,1132$ (C-O stretching), 750 (Aromatic $-\mathrm{CH}$ out of plane bending) $\mathrm{cm}^{-1} \cdot{ }^{1} \mathbf{H}$ NMR: (DMSO- $\left.d 6\right) \delta=6.98(\mathrm{~d}$, $J=7.9 \mathrm{~Hz}, 1 \mathrm{H}$, Ar-H), 7.30-7.43 (dd, $J=7.8,8.2$, $1.8 \mathrm{~Hz}, 5 \mathrm{H}, \mathrm{Ar}-\mathrm{H}), 7.58(\mathrm{~d}, J=8.2,1.9 \mathrm{~Hz}, 1 \mathrm{H}$, Ar-H), $7.93(\mathrm{~d}, J=8.5,1.6 \mathrm{~Hz}, 1 \mathrm{H}, \mathrm{Ar}-\mathrm{H}), 8.83(\mathrm{~s}$, $1 \mathrm{H}$, Ar-H), 9.96 (s, 2H, - $\left.\mathrm{NH}_{2}\right), 10.12(\mathrm{~s}, 1 \mathrm{H},-\mathrm{OH})$ ppm. MS (m/z): $277.1(\mathrm{M}+1,98 \%), 276.1\left(\mathrm{M}^{+}, 26 \%\right)$, 275.1 (22\%), 250.1 (89\%) 248.2 (65\%), $232.2(23 \%)$ 124 (24\%). Anal. Calcd. for $\mathrm{C}_{17} \mathrm{H}_{12} \mathrm{~N}_{2} \mathrm{O}_{2}$ : C, 73.90; H, 4.38; N, 10.14. Found: C, 73.87; H, 4.48; N, 10.03.

$2.7 \mathrm{~b}$ 4-(1,3-Benzoxazol-2-yl)-2-phenylnaphtho[1,2-d] [1,3] oxazole (8): $\mathbf{M p : ~} 210-212^{\circ} \mathrm{C}$. FT-IR (KBr): 3040 (Aromatic $-\mathrm{CH}$ streching), 1615, $1576(\mathrm{C}=\mathrm{C}$, 
$\mathrm{C}=\mathrm{N}$ ring stretching), 1217, 1126 (C-O stretching), 740, 695 (Aromatic - $\mathrm{CH}$ out of plane bending vibration) $\mathrm{cm}^{-1} .{ }^{1} \mathbf{H}$ NMR: $\left(\mathrm{CDCl}_{3}\right) \delta=7.43-7.46(\mathrm{~m}, J=$ 8.2, $2.1 \mathrm{~Hz}, 2 \mathrm{H}, \mathrm{Ar}-\mathrm{H}), 7.59-7.66(\mathrm{~m}, J=8.4,1.8 \mathrm{~Hz}$, $4 \mathrm{H}, \mathrm{Ar}-\mathrm{H}), 7.73-7.84$, (m, $J=8.7,7.3,0.2 \mathrm{~Hz}, 2 \mathrm{H}$, Ar-H), $7.94(\mathrm{dd}, J=7.2,2.1 \mathrm{~Hz}, 1 \mathrm{H}, \mathrm{Ar}-\mathrm{H}), 8.12$ $(\mathrm{d}, J=8.4 \mathrm{~Hz}, 1 \mathrm{H}, \mathrm{Ar}-\mathrm{H}), 8.48(\mathrm{dd}, J=8.1,1.8$, $3 \mathrm{~Hz}, 2 \mathrm{H}, \mathrm{Ar}-\mathrm{H}), 8.64$ (d, $J=8.1 \mathrm{~Hz}, 1 \mathrm{H}, \mathrm{Ar}-\mathrm{H}), 8.75$ (s, 1H, Ar-H) ppm. MS (m/z): $363.3(\mathrm{M}+1,100 \%)$, 277.3 (54\%), 251.6 (48\%), 233.1 (37\%). Anal. Calcd. for $\mathrm{C}_{24} \mathrm{H}_{14} \mathrm{~N}_{2} \mathrm{O}_{2}$ : C, 79.55; H, 3.89; N, 7.73. Found: C, $79.51 ; \mathrm{H}, 3.92$, N, 7.70.

\section{7c 4-(1,3-Benzoxazol-2-yl)-2-(4-nitrophenyl)}

naphtho[1,2-d][1,3]oxazole (9): $\mathbf{M p : ~}>300^{\circ} \mathrm{C}$. FTIR (KBr): 3042 (Aromatic-CH streching), 1624, 1575 $\left(\mathrm{C}=\mathrm{C}, \mathrm{C}=\mathrm{N}\right.$ ring stretching), 1538, $1330\left(-\mathrm{NO}_{2}\right) 1210$, 1126 (C-O stretching), 835, 740 (Aromatic -CH out of plane bending vibration) $\mathrm{cm}^{-1} .{ }^{1} \mathbf{H}$ NMR: $\left(\mathrm{CDCl}_{3}\right) \delta=$ 7.43-7.49 (m, $J=9.9,9.3 \mathrm{~Hz}, 2 \mathrm{H}, \mathrm{Ar}-\mathrm{H}), 7.64-7.82$ $(\mathrm{m}, J=7.8,7.9 \mathrm{~Hz}, 3 \mathrm{H}, \mathrm{Ar}-\mathrm{H}), 7.94(\mathrm{t}, J=9.3$, $1.5 \mathrm{~Hz}, 1 \mathrm{H}, \mathrm{Ar}-\mathrm{H}), 8.11$ (d, $J=8.1,1.8 \mathrm{~Hz}, 1 \mathrm{H}, \mathrm{Ar}-\mathrm{H})$, 8.43-8.46 (d, $J=9 \mathrm{~Hz}, 2 \mathrm{H}, \mathrm{Ar}-\mathrm{H}), 8.59-8.65$ (t, $J=$ 9.0, 7.2 Hz, 3H, Ar-H), 8.79 (s, 1H, Ar-H), ppm. MS $(\mathrm{m} / \mathrm{z}): 408.2(\mathrm{M}+1,99 \%), 407.3\left(\mathrm{M}^{+}, 21 \%\right), 378.1$ (23\%), 362.2 (90\%), 350.2 (12\%), 301.1 (19\%). Anal. Calcd. for $\mathrm{C}_{24} \mathrm{H}_{13} \mathrm{~N}_{3} \mathrm{O}_{4}$ : C, 70.76; H, 3.22; N, 10.31; Found: C, 70.71; H, 3.26; N, 10.39 .

2.7d 4-(1,3-Benzoxazol-2-yl)-2-(3-phenoxyophenyl) naphtho[1,2-d][1,3]oxazole (10): Mp: $160-162^{\circ} \mathrm{C}$. FT-IR (KBr): 3065 (Aromatic -CH streching), 1628, $1565(\mathrm{C}=\mathrm{C}, \mathrm{C}=\mathrm{N}$ ring stretching $), 1214,1134(\mathrm{C}-\mathrm{O}$ stretching), 780, 695 (Aromatic-CH out of plane bending vibration) $\mathrm{cm}^{-1} \cdot{ }^{1} \mathbf{H}$ NMR: (DMSO- $d 6$ ) $\delta=7.10$ $7.26(\mathrm{~m}, J=8.4,8.6,2.2 \mathrm{~Hz}, 4 \mathrm{H}, \mathrm{Ar}-\mathrm{H}), 7.41-7.47$ (m, $J=8.9,7.1,1.5 \mathrm{~Hz}, 4 \mathrm{H}, \mathrm{Ar}-\mathrm{H}), 7.52-7.78$ (m, $J=8.5$, 7.2, $1.8 \mathrm{~Hz}, 4 \mathrm{H}, \mathrm{Ar}-\mathrm{H}), 7.90(\mathrm{~m}, J=2.1,0.9 \mathrm{~Hz}, 1 \mathrm{H}$, Ar-H), 8.08-8.12 (d, $J=8.1,1.8 \mathrm{~Hz}, 2 \mathrm{H}$, Ar-H), 8.22 $(\mathrm{d}, J=6.9,0.9 \mathrm{~Hz}, 1 \mathrm{H}, \mathrm{Ar}-\mathrm{H}), 8.60(\mathrm{~d}, J=8.4 \mathrm{~Hz}$, 1H, Ar-H), 8.74 (s, 1H, Ar-H) ppm. MS $(m / z): 455.3$ (M+1, 99\%), $454.1\left(\mathrm{M}^{+}, 57 \%\right), 362$ (47\%), 250 (38\%), 232 (41\%). Anal. Calcd. for $\mathrm{C}_{30} \mathrm{H}_{18} \mathrm{~N}_{2} \mathrm{O}_{3}: \mathrm{C}, 79.28 ; \mathrm{H}$, 3.99; N, 6.16. Found: C, 79.35; H, 3.89; N, 6.11.

2.7e 4-[4-(1,3-Benzoxazol-2-yl)naphtho [1,2-d][1,3] oxazol-2-yl]phenol (11): Mp: $272-275^{\circ} \mathrm{C}$. FT-IR (KBr): 3365, 3352 (O-H), 3045 (-CH streching), 1626, $1575(\mathrm{C}=\mathrm{C}, \mathrm{C}=\mathrm{N}$ ring stretching $), 1215,1122(\mathrm{C}-\mathrm{O}$ stretching), 845, 730 (Aromatic -CH out of plane bending vibration) $\mathrm{cm}^{-1} \cdot{ }^{1} \mathbf{H}$ NMR: (DMSO- $\left.d 6\right) \delta=6.90$ (t, $J=7.8,1.4 \mathrm{~Hz}, 1 \mathrm{H}, \mathrm{Ar}-\mathrm{H}), 7.00(\mathrm{~d}, J=7.9 \mathrm{~Hz}$, $1 \mathrm{H}, \mathrm{Ar}-\mathrm{H}), 7.10-7.18(\mathrm{t}, J=10.8,7.8 \mathrm{~Hz}, 2 \mathrm{H}, \mathrm{Ar}-$ H), 7.38-7.48, (m, $J=7.2,1.8 \mathrm{~Hz}, 2 \mathrm{H}, \mathrm{Ar}-\mathrm{H}), 7.58$ $(\mathrm{d}, 7.4 \mathrm{~Hz}, 1 \mathrm{H}, \mathrm{Ar}-\mathrm{H}), 7.68(\mathrm{~m}, J=8.2,1.8 \mathrm{~Hz}$, $1 \mathrm{H}, \mathrm{Ar}-\mathrm{H}$ ), 7.90-8.02 (dd, $J=9.2,1.2 \mathrm{~Hz}, 2 \mathrm{H}, \mathrm{Ar}-$ $\mathrm{H}), 8.36$ (dd, $J=8.1,1.5 \mathrm{~Hz}, 1 \mathrm{H}, \mathrm{Ar}-\mathrm{H}), 8.72(\mathrm{~d}$, $J=8.2 \mathrm{~Hz}, 1 \mathrm{H}, \mathrm{Ar}-\mathrm{H}), 8.84(\mathrm{~s}, 1 \mathrm{H}, \mathrm{Ar}-\mathrm{H}), 10.48(\mathrm{~s}$ $1 \mathrm{H}, \mathrm{Ar}-\mathrm{OH}) \mathrm{ppm} .{ }^{1} \mathbf{H}$ NMR $\left(\mathbf{D}_{2} \mathbf{O}\right.$ Exchange of Comp 11): $(\mathrm{DMSO}-d 6) \delta=4.81$ (s, 1H, H-OD), 6.90 (t, $J=7.8,1.4 \mathrm{~Hz}, 1 \mathrm{H}, \mathrm{Ar}-\mathrm{H}), 7.00(\mathrm{~d}, J=7.9 \mathrm{~Hz}$, $1 \mathrm{H}, \mathrm{Ar}-\mathrm{H}), 7.10-7.18(\mathrm{t}, J=10.8,7.8 \mathrm{~Hz}, 2 \mathrm{H}, \mathrm{Ar}-$ $\mathrm{H}), 7.38-7.48(\mathrm{~m}, J=7.2,1.8 \mathrm{~Hz}, 2 \mathrm{H}, \mathrm{Ar}-\mathrm{H}), 7.58$ $(\mathrm{d}, J=7.4 \mathrm{~Hz}, 1 \mathrm{H}, \mathrm{Ar}-\mathrm{H}), 7.68(\mathrm{~m}, J=8.2,1.8 \mathrm{~Hz}$, $1 \mathrm{H}, \mathrm{Ar}-\mathrm{H}$ ), 7.90-8.02 (dd, $J=9.2,1.2 \mathrm{~Hz}, 2 \mathrm{H}, \mathrm{Ar}-$ $\mathrm{H}), 8.36(\mathrm{dd}, J=8.1,1.5 \mathrm{~Hz}, 1 \mathrm{H}, \mathrm{Ar}-\mathrm{H}), 8.72(\mathrm{~d}$,

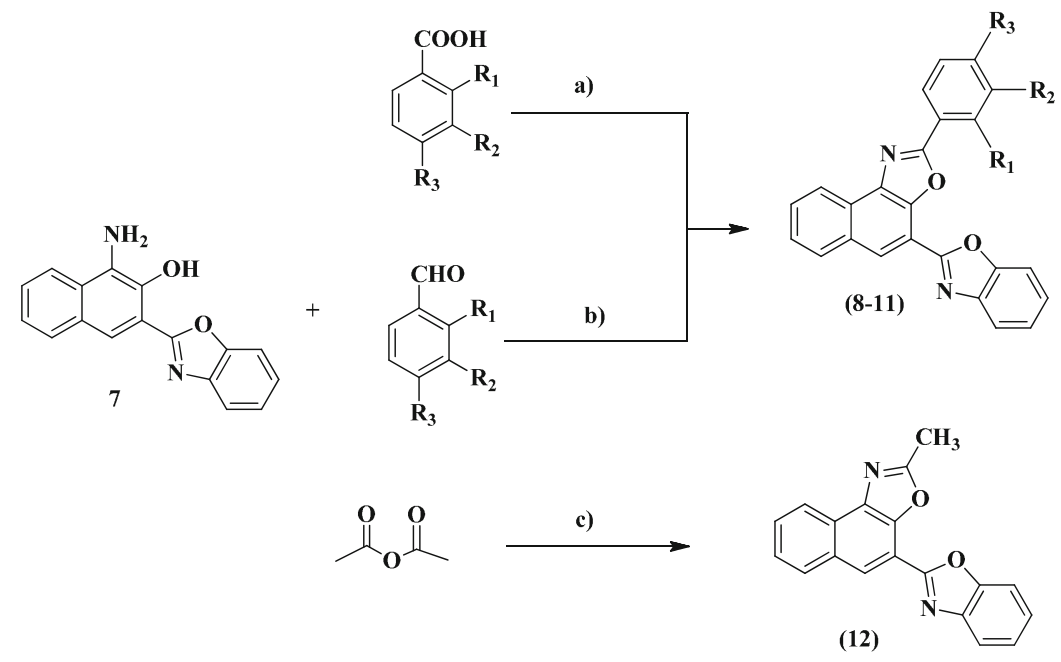

Scheme 2. Synthesis of 4-(1,3-benzoxazol-2-yl)-2-phenylnaphtho[1,2d] [1,3] oxazole derivatives (8-12). Reaction conditions: (a) Chlorobenzene, $\mathrm{PCl}_{3} 130-133^{\circ} \mathrm{C}, 16-18 \mathrm{~h}(57-65 \%)$; (b) DMSO, $158-160^{\circ} \mathrm{C}, 10-12 \mathrm{~h}$ (62-72\%); (c) $100-104^{\circ} \mathrm{C}, 1-1.5$ h (73\%). 
$J=8.2 \mathrm{~Hz}, 1 \mathrm{H}, \mathrm{Ar}-\mathrm{H}), 8.84(\mathrm{~s}, 1 \mathrm{H}, \mathrm{Ar}-\mathrm{H}), \mathrm{ppm}$. MS $(\mathrm{m} / \mathrm{z}): 379.6(\mathrm{M}+1,91 \%), 378\left(\mathrm{M}^{+}, 51 \%\right), 362.2$ (58\%), 350.2 (52\%), 277.2 (16\%), 261.1 (27\%), 250.6 (76\%), $232.2(37 \%)$. Anal. Calcd. for $\mathrm{C}_{24} \mathrm{H}_{14} \mathrm{~N}_{2} \mathrm{O}_{3}: \mathrm{C}$, 76.18; H, 3.73; N, 7.40; Found: C, 76.69; H, 3.82; $\mathrm{N}, 7.56$.

$2.7 f \quad 4-(1,3-B e n z o x a z o l-2-y l)-2-m e t h y l n a p h t h o[1,2-$

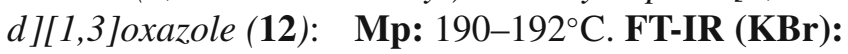
3055 (Aromatic $-\mathrm{CH}$ streching), 1616, $1555(\mathrm{C}=\mathrm{C}$, $\mathrm{C}=\mathrm{N}$ ring stretching), 1205, 1110 (C-O stretching), 740 (Aromatic $\mathrm{C}-\mathrm{H}$ out of plane bending vibration) $\mathrm{cm}^{-1} .{ }^{1} \mathbf{H}$ NMR: $(\mathrm{DMSO}-d 6) \delta=2.64\left(\mathrm{~s}, 3 \mathrm{H},-\mathrm{CH}_{3}\right)$,
7.35-7.43 (m, $J=7.8,6.9,1.4 \mathrm{~Hz}, 2 \mathrm{H}, \mathrm{Ar}-\mathrm{H}), 7.52-$ $7.78(\mathrm{~m}, J=8.8,7.6,2.2 \mathrm{~Hz}, 5 \mathrm{H}, \mathrm{Ar}-\mathrm{H}), 8.12(\mathrm{~d}, J=$ $8.1 \mathrm{~Hz}, 1 \mathrm{H}), 8.96(\mathrm{~s}, 1 \mathrm{H}, \mathrm{Ar}-\mathrm{H}) \mathrm{ppm}$. MS $(\boldsymbol{m} / \mathbf{z}): 301.7$ $(\mathrm{M}+1,100 \%), 300.2\left(\mathrm{M}^{+}, 51 \%\right), 260.1(16 \%), 250.2$ (89\%), 232.2 (32\%). Anal. Calcd. for $\mathrm{C}_{19} \mathrm{H}_{12} \mathrm{~N}_{2} \mathrm{O}_{2}$ : C, 75.99; H, 4.03; N, 9.33; Found: C, 75.89; H, 4.12; N, 9.26.

\section{Results and discussion}

The synthetic scheme for the preparation of 4-(1,3benzoxazol-2-yl)-2-phenylnaphtho[1,2- $d][1,3]$ oxazole

Table 1. Synthesis of 4-(1,3-benzoxazol-2-yl)naphtho[1,2- $d][1,3]$ oxazole derivatives from intermediate 7 and substituted aromatic aldehydes ${ }^{\mathrm{a}}$.

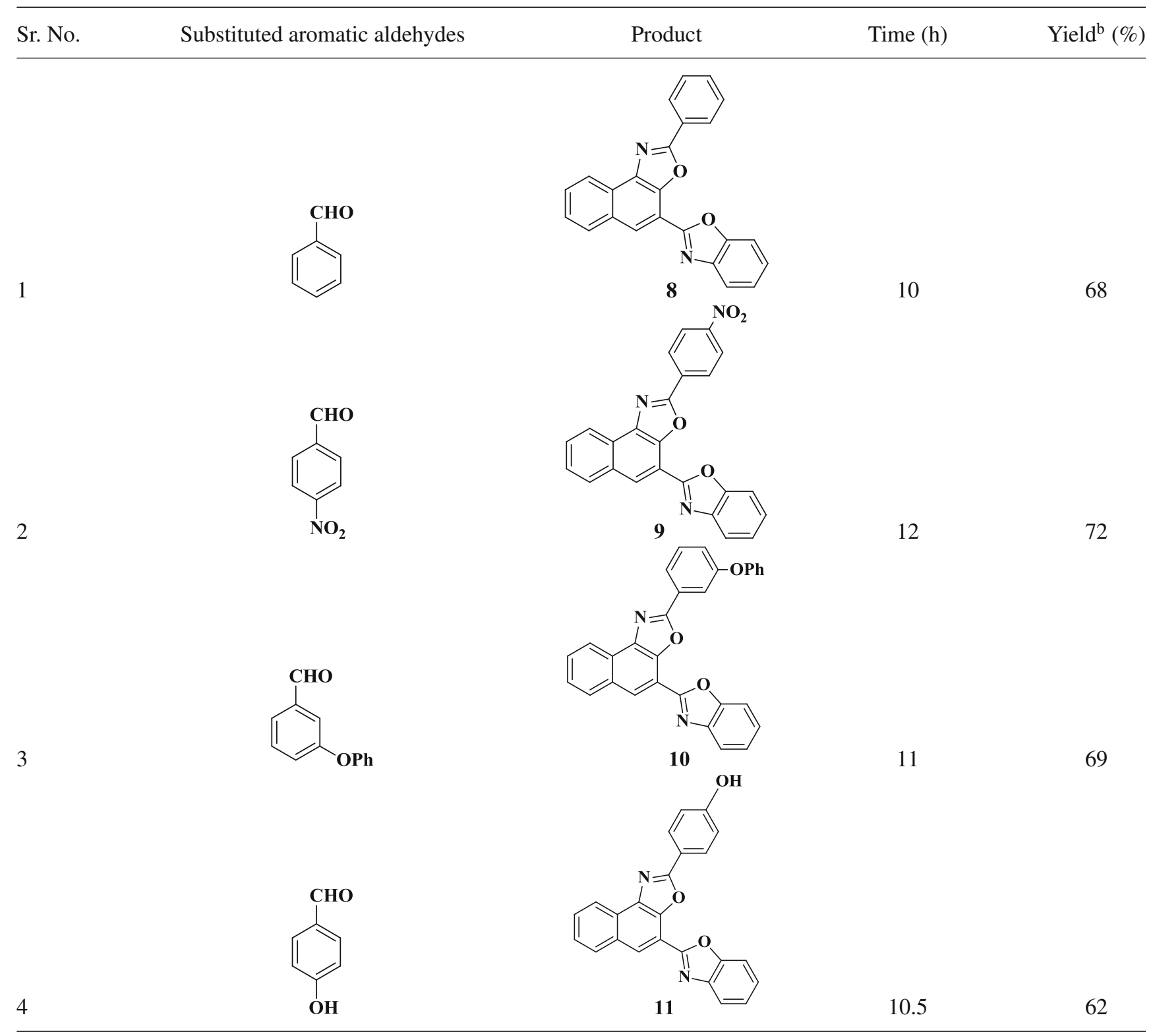

a Solvent: DMSO, Temp: $158-160^{\circ} \mathrm{C}$, Time: $10-12 \mathrm{~h}$.

${ }^{\mathrm{b}}$ Isolated yield 
derivatives is shown in schemes 1 and 2. 3-(1,3Benzoxazol-2-yl) naphthalen-2-ol 3 was prepared by reported procedure from 3-hydroxynaphthalene-2carboxylic acid $\mathbf{1}$ and 2-aminophenol $\mathbf{2}$ in the presence of $\mathrm{PCl}_{3}$ in chlorobenzene at $130-135^{\circ} \mathrm{C} .{ }^{25}$ Sulphanilic acid was diazotized to get 4-sulphobenzenediazonium chloride $\mathbf{5}$, which was further coupled with $\mathbf{3}$ to get azo compound $\mathbf{6}$. This azo compound $\mathbf{6}$ was reduced by using sodium dithionate at $\mathrm{pH} \mathrm{8-9}$ to get 1-amino-3(1,3-benzoxazol-2-yl)naphthalene-2-ol $\mathbf{7}^{26}$ (scheme 1) which was confirmed by FT-IR, ${ }^{1} \mathrm{H}-\mathrm{NMR}$, mass spectral analysis and its $\mathrm{M}+1$ peak was found to be at 277.1.
The series of 4-(1,3-benzoxazol-2-yl)-2-phenylnaphtho $[1,2-d][1,3]$ oxazole derivatives were synthesized by three different routes from intermediate 1-amino-3(1,3-benzoxazol-2-yl) naphthalen-2-ol 7 as shown in scheme 2. Compound 7 on treatment with different aromatic acids in the presence of phosphorus trichloride $\left(\mathrm{PCl}_{3}\right)$ in chlorobenzene at reflux temperature $(130$ $133^{\circ} \mathrm{C}$ ) for $15-18 \mathrm{~h}$ or with different aromatic aldehydes in dimethylsulphoxide at $158-160^{\circ} \mathrm{C}$ for 10 $12 \mathrm{~h}$ gives 4-(1,3-benzoxazol-2-yl)naphtho[1,2-d][1,3] oxazole derivatives 8-11. Substituted aromatic aldehyde gives product with good yield in short reaction

Table 2. Synthesis of 4-(1,3-benzoxazol-2-yl)naphtho[1,2- $d][1,3]$ oxazole derivatives from intermediate 7 and substituted aromatic carboxylic acids ${ }^{\mathrm{c}}$.

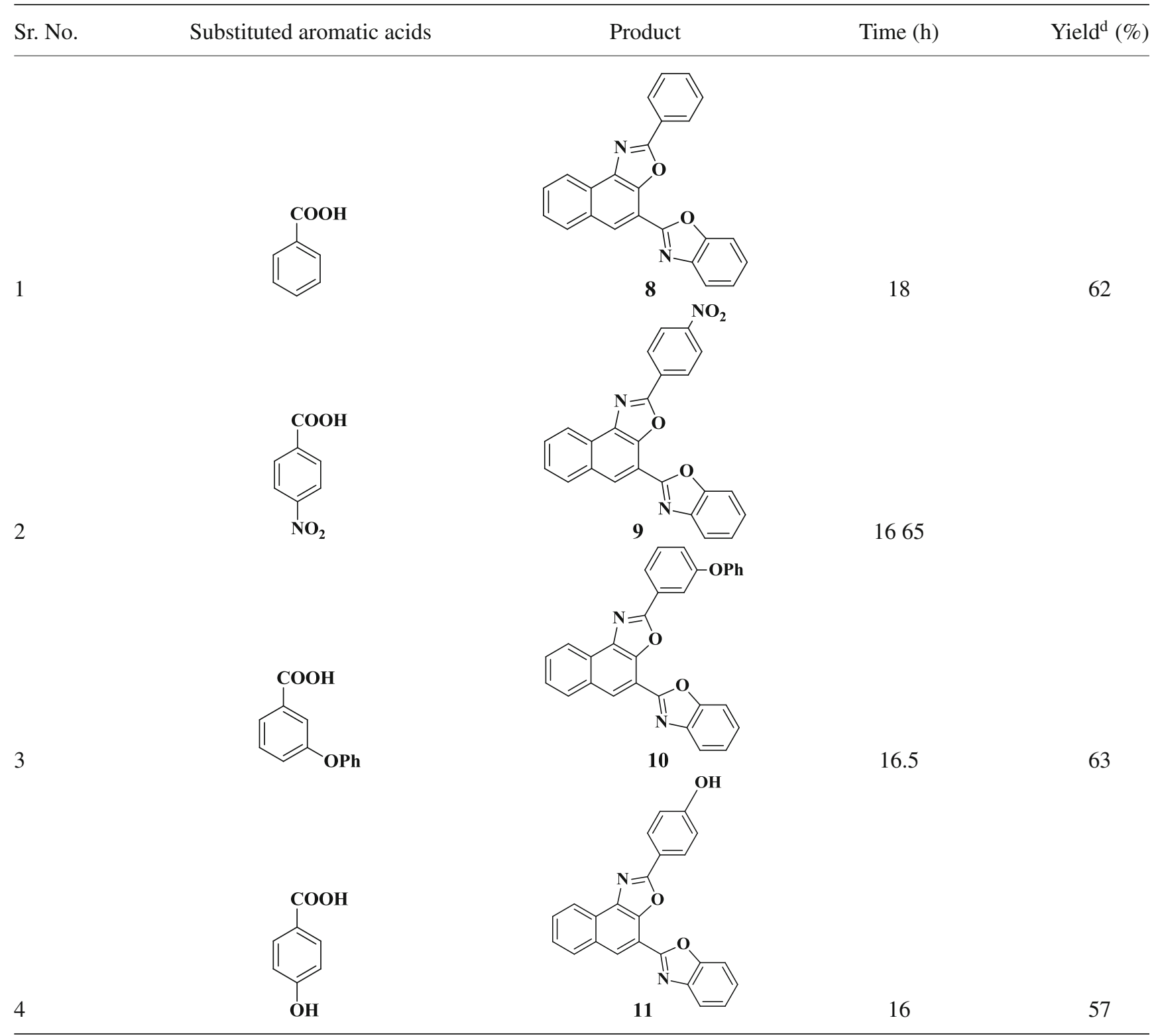

'Solvent: Chlorobenzene, Reagent: $\mathrm{PCl}_{3}$ Temp: $130-133^{\circ} \mathrm{C}$, Time: $16-18 \mathrm{~h}$.

${ }^{\mathrm{d}}$ Isolated yield 


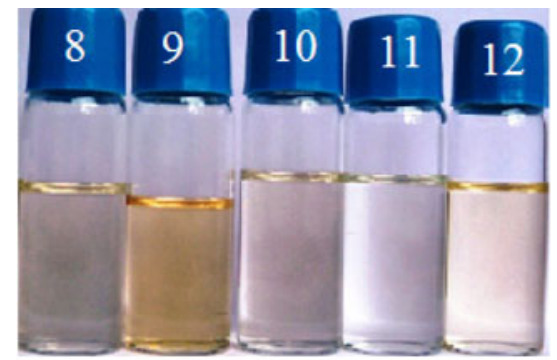

(a)

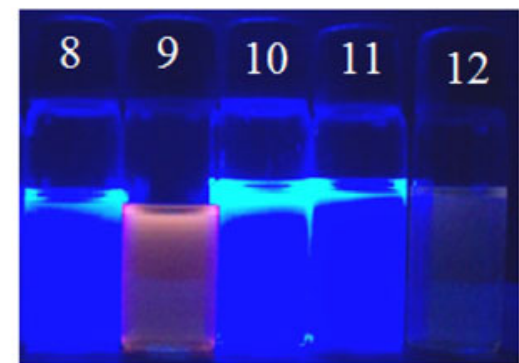

(b)

Figure 2. Day light and UV light photographs of the molecules in DMF. (a) Day light photograph and (b) UV-light photograph.

time (table 1) as compared to substituted aromatic acids (table 2).

Treatment of 7 with acetic anhydride at reflux temperature furnishes 4-(1,3-benzoxazol-2-yl)-2methylnaphtho[1,2- $d][1,3]$ oxazole 12. All synthesized compounds were confirmed by FT-IR, ${ }^{1} \mathrm{H}$ NMR and mass spectral analysis. FT-IR spectra of compound $\mathbf{9}$ shows peak at 1538 and $1330 \mathrm{~cm}^{-1}$ clearly indicates the presence of $-\mathrm{NO}_{2}$ group in the structure. Compound 11 shows distinct peak for $-\mathrm{OH}$ in FTIR at 3352$3365 \mathrm{~cm}^{-1}$ and phenolic $-\mathrm{OH}$ signal at $10.48 \delta \mathrm{ppm}$ in ${ }^{1} \mathrm{H}-\mathrm{NMR}$ and was confirmed by $\mathrm{D}_{2} \mathrm{O}$ exchange. The phenolic $-\mathrm{OH}$ peaks were disappeared in $\mathrm{D}_{2} \mathrm{O}$ exchange with additional peak at 4.80-4.82 $\delta \mathrm{ppm}$. Mass spectral data for compounds $\mathbf{9}$ and $\mathbf{1 2}$ show $\mathbf{M}+1$ peak at 408.2 and 301.1 , respectively which are in well agreement with their molecular weight.

\subsection{Biological activity}

All compounds were evaluated for in vitro antibacterial activities against $E$. coli and $S$. aureus strains and in vitro antifungal activity against $C$. albicans and $A$. niger strains by using serial dilution method.

\subsection{General}

Incubator at $37^{\circ} \mathrm{C}$; pipettes of various sizes (Gilson); sterile tips, 100, 200, 500, and $1000 \mu \mathrm{L}$; sterile normal saline; sterile isosensitest agar (Southern Group Laboratory, SGL); antibiotic solutions (Sigma-Aldrich); sterile solution of $10 \%$ (v/v) DMSO in water (SigmaAldrich) were used. Isosensitest medium was used throughout the assay, as it is $\mathrm{pH}$ buffered. Although NCCLS recommends the use of Mueller Hinton medium for susceptibility testing, ${ }^{27}$ the isosensitest medium had comparable results for most of the tested bacterial strains. ${ }^{28}$

\subsection{Preparation of the plates}

Plates were prepared under aseptic conditions. A sterile 96 well plate was labelled. A volume of $100 \mu \mathrm{L}$ of test material in $10 \%(\mathrm{v} / \mathrm{v})$ DMSO (usually a stock concentration of $4 \mathrm{mg} / \mathrm{ml}$ ) was pipetted into the first row of the plate. To all other wells $50 \mu \mathrm{L}$ of nutrient broth was added. Serial dilutions were performed using a multichannel pipette. Tips were discarded after use such that each well had $50 \mu \mathrm{L}$ of the test material in serially descending concentrations. To each well, $10 \mu \mathrm{L}$ of resazurin indicator solution was added. Using a pipette $30 \mu \mathrm{L}$ of $3.3 \times$ strength isosensitized broth added to each well to ensure that the final volume was single strength of the nutrient broth. Finally, $10 \mu \mathrm{L}$ of bacterial suspension $\left(5 \times 10^{6} \mathrm{cfu} / \mathrm{mL}\right)$ was added to each well to achieve a concentration of $5 \times 10^{5} \mathrm{cfu} / \mathrm{mL}$. Each plate was wrapped loosely with cling film to ensure that bacteria did not become dehydrated. Each plate had a set of controls: a column with a broad-spectrum antibiotic as positive control, a column with all solutions with the exception of the test compound, and a column with all solutions with the exception of the bacterial solution, adding $10 \mu \mathrm{L}$ of nutrient broth instead. The plates were

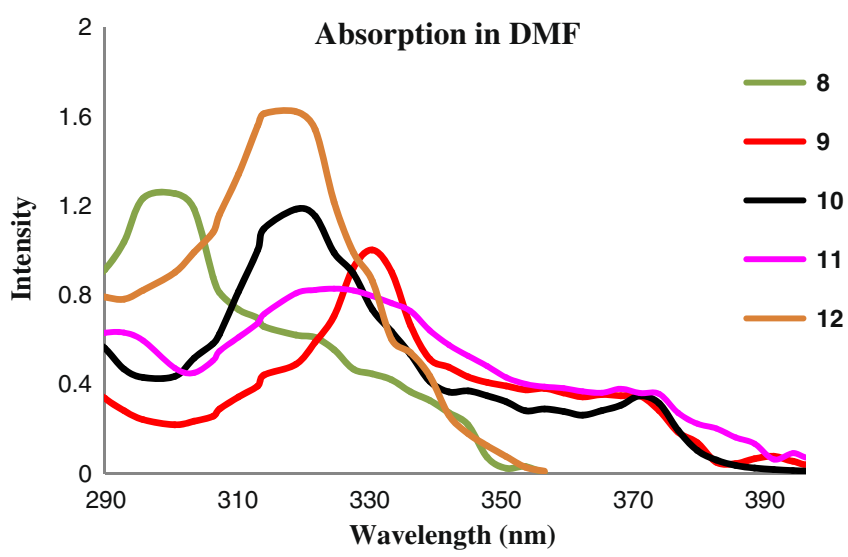

Figure 3. Absorption of compounds 8-12 in DMF. 


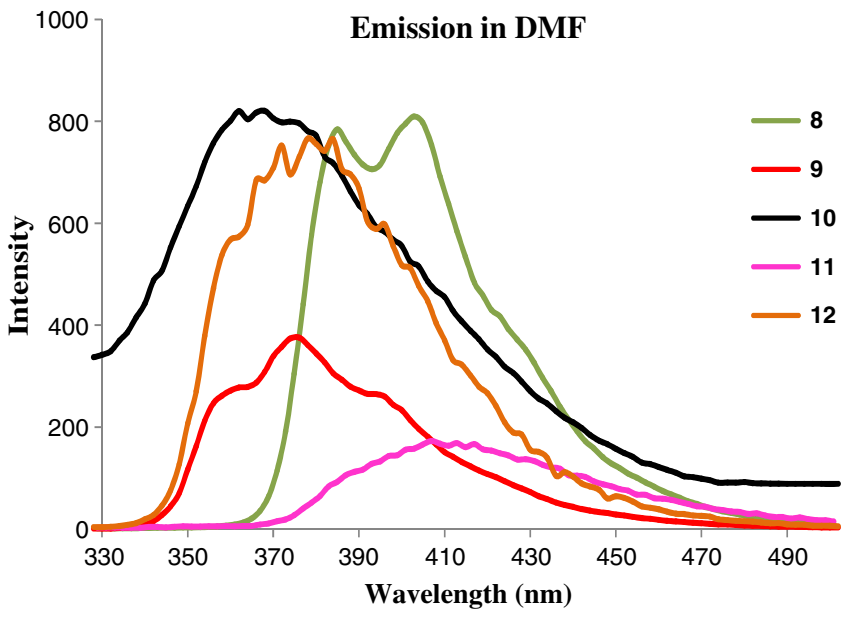

Figure 4. Emission of compounds 8-12 in DMF.

prepared in triplicate, and placed in an incubator set at $37^{\circ} \mathrm{C}$ for $18-24 \mathrm{~h}$. The colour change was assessed visually. Any colour changes from purple to pink or colourless were recorded as positive. The lowest concentration at which colour change occurred was taken as the MIC value. The average of three values was calculated and that was the MIC for the test material and bacterial or fungal strain. ${ }^{29}$

\subsection{Photophysical properties}

All synthesized compounds are fluorescent (figure 2b) and were studied for their photophysical properties. Their absorption and emission properties were recorded in DMF. All these compounds absorb from 296 to $332 \mathrm{~nm}$ (figure 3) and emit from 368 to $404 \mathrm{~nm}$ (figure 4) with good Stokes shift ranges from 39 to $108 \mathrm{~nm}$. Out of these compounds, compound $\mathbf{8}$ shows good Stokes shift with $108 \mathrm{~nm}$. As compared to compound 9, compound $\mathbf{1 1}$ shows larger Stokes shift, this property attributed due to electron donating ability of -OH in compound $\mathbf{1 1}$ for easy flow of electron from

Table 3. Absorption and emission at $1 \times 10^{-6} \mathrm{M}$ concentration of compounds 8-12 in DMF.

\begin{tabular}{lccc}
\hline Compounds & $\begin{array}{c}\text { Absorption } \\
\lambda_{\max }(\mathrm{nm})\end{array}$ & $\begin{array}{c}\text { Emission } \\
\lambda_{\max }(\mathrm{nm})\end{array}$ & $\begin{array}{c}\text { Stokes shift } \\
(\mathrm{nm})\end{array}$ \\
\hline $\mathbf{8}$ & 296 & 404 & 108 \\
$\mathbf{9}$ & 332 & 371 & 39 \\
$\mathbf{1 0}$ & 320 & 368 & 48 \\
$\mathbf{1 1}$ & 326 & 404 & 78 \\
$\mathbf{1 2}$ & 320 & 384 & 64 \\
\hline
\end{tabular}

Absorption $\lambda_{\max }$ and emission $\lambda_{\max }$ were measured in $\mathrm{nm}$. Samples were prepared in DMF.

Analyses were carried out at room temperature
Table 4. Quantum yield of compounds 8-12 in DMF.

\begin{tabular}{lc}
\hline Compound No & Quantum yield \\
\hline $\mathbf{8}$ & 0.206 \\
$\mathbf{9}$ & 0.129 \\
$\mathbf{1 0}$ & 0.308 \\
$\mathbf{1 1}$ & 0.047 \\
$\mathbf{1 2}$ & 0.274 \\
\hline
\end{tabular}

Absorption $\lambda_{\max }$ and emission $\lambda_{\max }$ were measured in $\mathrm{nm}$.

Samples were prepared in DMF.

Analyses were carried out at room temperature

4-OH phenyl ring to benzoxazole ring via fused naphthoxazole ring system and electron withdrawing ability of $-\mathrm{NO}_{2}$ in compound 9 (table 3 )

An effective compound for the biological application should have good fluorescent intensity, high quantum yield and high photostability. Quantum yield of all compounds were recorded by using tinopal as a reference standard. Absorption and emission characteristics of standard as well as unknown samples were measured at different concentration of unknown samples and standard at (2, 4, 6, 8 and $10 \mathrm{ppm}$ level). Absorbance intensity values were plotted against emission intensity values. A linear plot was obtained. Gradients were calculated for each unknown compound and for standard. All the measurements were done by keeping the parameters such as solvent and slit width constant. Relative quantum yield of all synthesized compounds 8-12 were calculated by using the formula $1 .^{30}$

Formula 1: Relative fluorescence quantum yield

$$
\Phi_{\mathrm{X}}=\Phi_{\mathrm{ST}}\left(\operatorname{Grad}_{\mathrm{X}} / \operatorname{Grad}_{\mathrm{ST}}\right)\left(\eta_{\mathrm{X}}^{2} / \eta_{\mathrm{ST}}^{2}\right),
$$

where

$\Phi_{\mathrm{X}}$ : $\quad$ Quantum yield of unknown sample

$\Phi_{\mathrm{ST}}$ : Quantum yield of standard used

$\operatorname{Grad}_{\mathrm{X}}$ : Gradient of unknown sample

$\operatorname{Grad}_{\mathrm{ST}}$ : Gradient of standard used

Table 5. Thermal gravimetric analysis (TGA) of compound $\mathbf{8} \mathbf{- 1 2}$.

\begin{tabular}{lc}
\hline Compound & TGA \\
\hline $\mathbf{8}$ & $222(97.50 \%)$ \\
$\mathbf{9}$ & $223(98.41 \%)$ \\
$\mathbf{1 0}$ & $236(98.34 \%)$ \\
$\mathbf{1 1}$ & $216(99.67 \%)$ \\
$\mathbf{1 2}$ & $255(98.12 \%)$ \\
\hline
\end{tabular}

TGA was measured in ${ }^{\circ} \mathrm{C}$ 


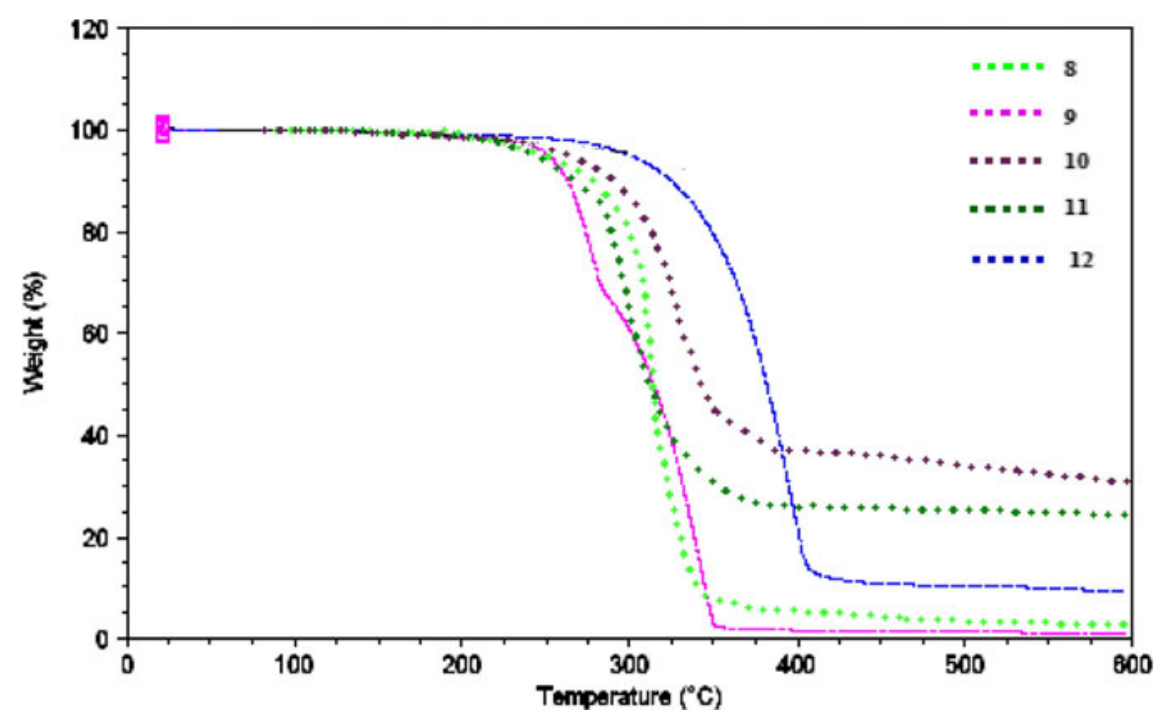

Figure 5. TGA curves of compound 8-12.

$\eta_{\mathrm{X}}^{2}: \quad$ Refractive index of solvent for standard sample

$\eta_{\mathrm{ST}}^{2}: \quad$ Refractive index of solvent for sample.

The fluorescence quantum yields of all compounds were recorded in DMF at room temperature as shown in table 4. Quantum yields of all compounds are found to be good and ranges from 0.047 to 0.308 (table 4).

\subsection{Thermal stability}

To investigate the thermal stability of synthesized compounds 8-12 the thermal stability studies have been carried out using thermo gravimetric analysis (TGA) technique. The thermal gravimetric analysis has been carried out in the temperature range of $50-600^{\circ} \mathrm{C}$ under nitrogen atmosphere. TGA result in table indicates that the naphthoxazole ring skeleton is $98 \%$ stable up to $216^{\circ} \mathrm{C}$ (compound 11). Above this temperature all compounds start to decompose and show the major loss in weight. The compound $\mathbf{1 2}$ shows the highest thermal stability up to $255^{\circ} \mathrm{C}(98.12 \%)$. The comparison of $T_{d}$ (decomposition temperature) showed that the thermal stability of the compound 8-12 decreases in the order $\mathbf{1 2}>\mathbf{1 0}>\mathbf{9}>\mathbf{8}>\mathbf{1 1}$ as shown in table 5. TGA analysis curve of the compounds $\mathbf{8 - 1 2}$ is as shown in figure 5.

\subsection{Antimicrobial activity}

The novel compounds 8-14 were evaluated for their in vitro antibacterial activity against $E$. coli and $S$. aureus strains and in vitro antifungal activity against $C$. albicans and $A$. niger strains by using serial dilution method. The minimum inhibitory concentration (MIC) was determined for the compounds. The MIC $(\mu \mathrm{g} / \mathrm{mL})$ values recorded in table 6 indicate that most of the tested compounds showed variable inhibitory growth effects against tested bacterial and fungal strains. Antimicrobial data were compared with standard drug Streptomycin and Fluconazole.

The MIC values from table 6 reveals that compound 10, 11 and 12 showed good to moderate activity against $E$. coli and $S$. aureus. Compound $\mathbf{8}$ shows activity against $S$. aureus while compound 9 showed good activity against $E$. coli.

As compared to the antibacterial activity all synthesized compounds (8-12) showed good antifungal activity against antifungal strains $C$. albicans and $A$. niger. Results mentioned in table 6 showed that compounds

Table 6. Antibacterial and antifungal activities of newly synthesized compounds indicated by MIC $(\mu \mathrm{g} / \mathrm{mL})$ using the modified resazurin assay.

\begin{tabular}{lccccc}
\hline \multirow{2}{*}{ Compounds } & \multicolumn{2}{c}{ Bacterial strain } & & \multicolumn{2}{c}{ Fungal strain } \\
\cline { 2 - 3 } \cline { 5 - 6 } & E. coli & S. aureus & & C. albicans & A. niger \\
\hline $\mathbf{8}$ & 625 & 156.2 & & 156.2 & 78 \\
$\mathbf{9}$ & 156.2 & 625 & & 78 & 78 \\
$\mathbf{1 0}$ & 156.2 & 156.2 & & 312.5 & 312.5 \\
$\mathbf{1 1}$ & 156.2 & 156.2 & & 78 & 78 \\
$\mathbf{1 2}$ & 156.2 & 156.2 & & 156.2 & 156.2 \\
Streptomycin & 125 & 125 & & - & - \\
Fluconazole & - & - & & 125 & 125 \\
\hline
\end{tabular}

Antimicrobial activities were expressed in MIC.

MIC: Minimal inhibitory concentration values.

Bacterial strain: E. coli; S. aureus.

Fungal Strain: C. albicans; A. niger.

Solvent used: DMSO (Dimethyl sulphoxide).

Standard: Bacterial strain: Streptomycin- $125 \mu \mathrm{g} / \mathrm{mL}$, Fungal strains: Fluconazole- $125 \mu \mathrm{g} / \mathrm{mL}$. 
8, 9, 11 and 12 showed good inhibition of growth in case of $C$. albicans as well as A. niger while compound 10 showed moderate activity against both antifungal strain. Electron donating and electron withdrawing groups present on phenyl ring does not affect the growth inhibitory activity against tested bacterial and fungal strains.

In general, most of the tested compounds revealed better activity against the antibacterial strain (E. coli, $S$. aureus) and antifungal strain (C. albicans, $A$. niger). Novel compounds are reactive against fungal strain as compared to bacterial strain tested over microorganisms.

\section{Conclusion}

We have designed and synthesized a series of novel 4-(1,3-benzoxazol-2-yl)-2-phenylnaphtho[1,2$d] 1,3$ ]oxazole derivatives. The photophysical property study shows that all are fluorescent and absorbs from 296 to $332 \mathrm{~nm}$ while emits in the ranges of 368 to $404 \mathrm{~nm}$ with excellent quantum yield. These novel compounds were evaluated for in vitro antibacterial activity against $E$. coli and $S$. aureus and antifungal activity against $C$. albicans and $A$. niger using serial dilution technique. The synthesized compounds show good antifungal activity than that of antibacterial. All synthesized compounds were confirmed by FT-IR, ${ }^{1} \mathrm{H}$ NMR and mass spectral analysis. We believe that the insights gained in this study would be useful for the development of potential drug candidates derived from naphtho $[1,2-d][1,3]$ oxazole derivatives in the development of novel antiinfective agents.

\section{Acknowledgements}

The authors are thankful to sophisticated analytical instrument facility (SAIF), Indian Institute of Technology (IIT) Mumbai for providing the ${ }^{1} H$ NMR and Mass facility. One of the authors KRP is thankful to the University Grants Commission (UGC)-SAP for financial support.

\section{References}

1. (a) Devinder K, Jacob M R, Reynolds M B and Kerwin S M 2002 Biorg. Med. Chem. 10 3997; (b) Sato Y, Yamada M, Yoshida S, Soneda T, Ishikawa M, Nizato T, Suzuki K and Konno F 1998 J. Med. Chem. 41 3015; (c) Katz L 1953 J. Am. Chem. Soc. 75712

2. (a) Rodriguez A D, Ramirez C, Rodriguez I I and Gonzalez E 1999 Org. Lett. 1 527; (b) Kobayashi J, Madono T and Shigemori H 1995 Tetrahedron Lett. 36 5589
3. Tanaka K, Kumagai T, Aoki H, Deguchi M and Iwata S 2001 J. Org. Chem. 667328

4. Abbady M A 1966 Preparation and application of some new naphthoxazole dyes. M. Sc. Thesis, Assiut University Assiut, Egypt

5. Kumar A, Ahmad P, Maurya R A, Singh A B and Srivastava A K 2009 Eur. J. Med. Chem. 44109

6. Malamas M S, Sredy J, Katz Moxham A, Xu W X, Mcdevitt R, Adedayo F O, Sawiciki D R, Seetaller L, Sullivan L and Taylor J R $2000 \mathrm{~J}$. Med. Chem. 43 1293

7. Malamas M S, Sredy J, Gunavan I, Mihan B, Sawichi D R, Seestaller L, Sullivan D and Flam B R 2000 J. Med. Chem. 43995

8. Ertan T, Yildiz I, Tekiner-Gulbas B, Bolelli K, TemizArpaci O, Yalcin I, Aki E, Ozkan S and Kaynak F 2009 Eur. J. Med. Chem. 44501

9. Dunwell D W and Delme 1977 Eur. J. Med. Chem. 20 797

10. White A W, Curtin N J, Eastman B W, Golding B T, Hostomsky Z, Kyle S, Li J, Maegley K A, Skalitzky D J, Webber S E, Yu X H and Griffin R 2004 J. Bioorg. Med. Chem. Lett. 142433

11. Novelli F, Tasso B, Sparatore F and Sparatore A 1997 Farmaco $\mathbf{5 2} 499$

12. (a) McKee M L and Kerwin S M 2008 Bioorg. Med. Chem. 16 1775; (b) Oksuzoglu E, Temiz-Arpaci O, Tekiner-Gulbas B, Eroglu H, Sen G, Alper S, Yildiz I, Diril N, Aki-Sener E and Yalcin I 2008 Med. Chem. Res. 161

13. Sun L Q, Chen J, Bruce M, Deskus J A, Epperson J R, Takaki K, Johnson V G, Iben L, Mahle C D, Ryan E and Xu C 2004 Bioorg Med. Chem. Lett. 143799

14. (a) Costa S P G, Oliveira E, Lodeiro C and Raposo M M 2007 Sensors 7 2096; (b) Shamsipur M, Poursaberi T, Karami A R, Hosseini M, Momeni A, Alizadeh N, Yousefi M and Ganjali M R 2004 Anal. Chim. Acta. 501 55; (c) Zang X B, Peng J, He C L, Shen G L and Yu R Q 2006 Anal. Chim. Acta. 567189

15. (a) Heathcock C H 1991 In: Comprehensive organic synthesis B M Trost, and I Flemming (eds) New York: Pergamon Press Vol 2; (b) Varga A, Aki Sxener E, Yalcin I, Temiz Arpaci O, Tekiner Gulbasx B, Cherepnev G and Molnar J 2005 In Vivo 191087

16. Yousuke O, Haruka E and Katsuhira Y 2009 Dyes Pigments 8258

17. Ooyama Y, Nonami K, Watanabe S and Yoshida K 2008 Dyes Pigments $\mathbf{7 7} 315$

18. (a) Padalkar V S, Borse B N, Gupta V D, Phatangare K R, Patil V S and Sekar N 2011 J. Het. Chem. (Article Accepted, Manuscript ID: JHET-11-0566.R1); (b) Padalkar V S, Borse B N, Gupta V D, Phatangare K R, Patil V S, Umape P G and Sekar N 2011 Arab. J. Chem (Article Accepted, doi:10.1016/j.arabjc.2011.12.006)

19. Reynolds M b, DeLuca M R and Kerwin S M 1999 Bioorg. Chem. 27326

20. Devinder K, Melissa R J, Michael B R and Sean M K 2002 Bioorg. Med. Chem. 103997

21. Xu Y and Pang Y 2010 Chem. Commun. 464070

22. Kim T I, Kang H J, Han G, Chung S J and Kim Y 2009 Chem. Commun. 455895

23. Chen W, Wright B D and Pang Y 2012 Chem. Commun. 483824 
24. Yan L, Ye Z, Peng C and Zhang S 2012 Tetrahedron 68 2725

25. Matsui, Kuroda 1967 Kogyo Kagaku Zasshi 702325

26. Rangnekar D W and Rajadhyaksha D D 1986 Dyes Pigments 7365

27. National Committee for Clinical Laboratory Standards. Methods for dilution antimicrobial susceptibility tests for bacteria that grow aerobically. Approved standard
M7-A4. 2000 National Committee for Clinical Laboratory Standards, PA: Wayne

28. Koeth L M, King A, Knight May J, Miller Phillips I and Poupard J A 2000 J. Antimicrob. Chemother. 46369

29. Sarker S D, Nahar L and Kumarasamy Y 2007 Methods 42321

30. Padalkar V S, Tathe A B, Gupta V D, Patil V S, Phatangare K R and Sekar N 2012 J. Fluoresc. 22311 